\title{
World karst science reviews
}

\section{Cave and Karst Science}

of British Cave Research Association

Volume 37, (1) , 2010

\section{CONTENTS}

Monitoring the population of the linyphid spider Porrhomma rosenhaueri (L. Koch, 1872)

(Araneae: Linyphiidae) in Lesser Garth Cave, Cardiff, UK.

Julian Carter, Adrian Fowles and Catalena Angele

Derbyshire pipe veins - deep-seated speleogenesis.

Trevor D. Ford

$21^{\text {st }}$ British Cave Research Association Cave Science Symposium Abstracts: University of Bristol, 6 March 2010

\section{International Journal of Speleology}

Of the International Union of Speleology

Volume 39(2), July 2010

\section{CONTENTS}

Results of palaeomagnetic research of karst sediments in Slovenia.

Nadja Zupanhajna, Andrej Mihevc, Petr Pruner and Pavel Bosak

Spatial distribution of soda straws growth rates of the Coufin Cave (Vercors, France).

Yves Perrette and Stéphane Jaillet

Karst geology and cave fauna of Austria: a concise review.

Erhard Christian and Christoph Spotl

Modern $\mathrm{C}, \mathrm{O}$ and $\mathrm{H}$ isotope composition of speleothem and dripwater from Modrič Cave, Eastern Adriatic (Croatia).

Maa Suri, Zvjezdana Roller-Lutz, Magda Mandi, Ines Krajcar Broni, Mladen Jura

Uranium-series age data and revised stable isotope curves for New Zealand speleothems:

frequency distribution, sample depth and palaeoclimatic implications.

Paul W. Williams, J-X Zhang, H. Neil

A re-appraisal of the stratigraphy, palaeontology and dating of Cow Cave, Chudleigh, Devon, England. Jim W. Simons

Do Karst Rivers "deserve" their own biotic index? A ten years study on macrozoobenthos in Croatia. Biljana Raa and Sanja Puljas

BooK REvIEW - Angel Ginés, Martin Knez, Tadej Slabe \& Wolfgang Dreybrodt 2009 Karst rock feature Karren sculpturings, Carsologica 9, Postojna/Ljubljana.

Jo De Waele 


\author{
Journal of Cave and Karst Studies \\ of the National Speleological Society \\ Volume 72(1), April 2010
}

\title{
CONTENTS
}

Stochastic modelling of surface stream flow at different time scales: Sangsoorakh Karst Basin, Iran. M. Reza Ghanbarpour, Karim C. Abbaspour, Goudarz Jalavand, and Ghodsieh Ashtiani Moghaddam

Distribution of cyanobacteria at the Gelada Cave (Spain) by physical paramters.

Antonia Martinez and Antonia Dolores Asencio

Direct measurement of present-day tectonic movement and associated radon flux in Postojna Cave, Slovenia. Stanka Šebela, Janja. Vaupotič, Blahoslav Košt ták, and Josef Stemberk

Developing a GIS-based inventory for the implementation of cave management protocols in Withlacoochee State Forest, Florida.

Grant L. Harvey, Philip P. Reeder, Jason S. Polk, and Philip E. van Beynen

The sulfidic thermal caves of Acquasanta Terme (Central Italy).

Sandro Galdenzi, Filippo Cocchioni, Giampaolo Filipponi, Luciana Morichetti, Stefania Scuri,

Rosario Selvaggio, and Mario Cocchioni

BOOK REVIEW - Subterranean Twin Cities

Joseph C. Douglas

Journal of Cave and Karst Studies

of the National Speleological Society

Volume 72(2), August 2010

\section{CONTENTS}

Coastal cave in Bahamain eolian calcarenites: Differentiating between sea caves and flank margin caves using quantitative morphology.

Willapa J. Waterstrat, John E. Mylroie, Athena M. Owen, and Joan R. Mylroie

Secondary minerals in volcanic caves: Data from Hawai $i$.

William B. White

Description of a new Macrobrachium species (Crustacean: Caridea: Palaemondidae) from a cave in Guangxi, with a synopsis of the stygobiotic Decapoda in China.

Yitao Pan, Zhonge Hou, and Shuqiang Li

Ground-penetrating radar investigation of a rapidly developed small island in a lake in southern Georgia, USA. Can Denizman, Eric C. Brevik, and Jim Doolittle

The subterranean asellids of Maryland: Description of Caecidotea nordeni, new species, and new records of C. holsingeri and C. franzi (Crustacea: Malacostraca: Isopoda).

Julian J. Lewis and Thomas E. Bowman

Heperonemastoma smilax, n. sp., a remarkable new harvestman from a cave in West Virginia, with comments on other reported cave-dwelling Hesperonemastoma species (Opiliones, Ischyropsalidoidea, Sabaconidae).

William A. Shear

Stable isotopes of subfossil bat guano as a long-term environmental archive: Insights from a Grand Canyon cave deposit. Christopher M. Wurster, Donald A. McFarlane, Michael I. Bird, Philippa Ascough, and Nancy Beavan Athfield 
Upper Pleistocene Gulo gulo (Linné, 1758) remains from the Srbsko Chlum-Komin hyena den cave in the Bohemian Karst, Czech Republic, with comparisons to contemporary wolverines.

Cajus G. Diedrich, and Jeffrey P. Copeland

BooK REVIEW — Geological Monitoring

Arthur N. Palmer

\section{Karstologia}

Of the Fedration Française de Spéléologie and Assocaiation Française de Karstologie

Volume 53, 2009

\section{CONTENTS}

Spatial and morphological analysis by high-resolution 3D modeling of a stalagmites forest in Orgnac's karstic network (Ardèche, France).

Souhail Hajri, Benjamin Sadier, Stéphane Jaillet, Estelle Ployon, Elisa Boche, Aiman Chakroun,

Georges-Marie Saulnier, Jean-Jacques Delannoy-

Use of natural canyoning sites in France : a socio-cultural approach..

André Suchet et Dominique Jorand

Pseudokarst in sandstone of the coastal eocene flysch, Guipuzcoa.

Carlos Galan, José Rivas et Marian Nieto

Carte des karsts autour de la Méditerranée et en Europe moyenne.

Jean Nicod

An example of karst water resources exploitation: snow production in Villard-de-Lans - Corrençon-en-Vercors (Isère, France)

Pierre Paccard 